\title{
EFFECT OF PRE-HARVEST FOLIAR APPLICATION OF CITRIC ACID, MALIC ACID AND TRYPTOPHAN ON THE GROWTH, FLOWERING AND POST-HARVEST VASE LIFE OF TUBEROSE PLANTS I- Effect of pre-harvest treatments on vegetative growth and flowering
}

(Received: 17-5-2015)

\author{
By \\ N. A. El-Shanhorey, A. M Shehata* and R. A. Soffar** \\ Department of Botanical Gardens Research - Antoniades, Horticultural Research Institute, \\ Agriculture Research Center, Alexandria, Egypt. \\ * Department of Floriculture, Ornamental Horticulture and Landscape Design, Faculty of \\ Agriculture, Alexandria University, Alexandria, Egypt. \\ ** Department of Ornamental Plants Research - Antoniades, Horticultural Research Institute, \\ Agriculture Research Center, Alexandria, Egypt.
}

\begin{abstract}
ABESTRACT
This study was carried out during the two seasons of 2013 and 2014 at the nursery, Department of Floriculture, Ornamental Horticulture and Landscape Gardening, Faculty of Agriculture, Alexandria University, Egypt. Tuberose (Polianthes tuberosa, L. cv. "Double") corms with average of $3.8 \mathrm{~cm}$ diameter and $70.0 \mathrm{~g}$ of fresh weight were planted in $30 \mathrm{~cm}$ diameter plastic pots, filled with $10 \mathrm{~kg}$. sandy soil , on $13^{\text {th }}$ May 2013 and 2014 in the first and second seasons, respectively. The plants were sprayed with Citric acid, Malic acid and Tryptophan at concentrations of 0, 100, 200 and 300 ppm, every 15 days from July $4^{\text {th }}$ till August $15^{\text {th }}$ in both seasons. Control plants were sprayed with tap water. The end of the experiment was September $1^{\text {st }}$ (in both seasons).

The obtained results showed that spraying Polianthes tuberosa plants with malic acid at $300 \mathrm{ppm}$ significantly increased plant height, leaf number, leaf dry weight, leaf area, time to showing color, the number of flowers per spike, flowering duration, flower dry weight, spike dry weight, rachis length, corm diameter, the number of new cormlets, total chlorophyll content, carbohydrate content and nitrogen percentage in the leaves. Spraying tryptophan at $200 \mathrm{ppm}$ resulted in increasing corm dry weight.
\end{abstract}

Key words: Polianthes tuberosa - Citric acid - Malic acid-Tryptophan.

\section{INTRODUCTION}

Tuberose (Polianthes tuberosa L.), a member of the Agavaceae family and native to Mexico, has long been cherished for the aromatic oils extracted from its fragrant white flowers (Trueblood, 1973). It has recently gained popularity as a cut flower and in a number of countries including Kenya, India and Mexico. It is grown commercially for export to the USA, Europe and Japan. Tuberose inflorescences (spikes) bear 10-20 pairs of florets which open acropetally. Commercially, spikes $60-90 \mathrm{~cm}$ long are harvested when two or three of the basal florets are open. Lesss than $50 \%$ of the buds normally open after harvest, and florets and buds usually abscond after only few days in the vase. Postharvest performance is worse in tuberose which has been shipped to distant markets. Since tuberose originated in the sub-tropics, this loss of quality might be due to chilling injury induced by exposure to low, but non-freezing, temperatures during marketing. Alternatively, it might be the result of postharvest desiccation, or improper temperature management.

Tuberose (Polianthes tuberosa L.) is a very popular cut flower in Egypt. It has white flowers having sweet scent. Its flowering occurs during summer and early autumn, when planted in spring. There are up to 30 flowers in one spike and the length of rachis varies between 14 and $28 \mathrm{~cm}$, depending upon the size of the planted corms. Besides being source of essential oils for perfume industry, it is commonly used in bouquets for presenting and in vases for interior decoration. The grading standard for tuberose marketing is a disease-free straight stem of about 
$70 \mathrm{~cm}$ and spike with a minimum of 10 pairs of pure white florets (Steenstra and Brundell 1986). Since it has delicate flowers so that the sellers and consumers are keen in extending its vaselife, this necessitates to improve its postharvest life. Keeping quality of the spikes is only 3 days per floret, and vase-life of the flowers is only few days.

Citric acid is a regular ingredient in many vase solution formulations that acts as a $\mathrm{pH}$ regulator that reduces bacterial proliferation and enhances water conductance in the xylem of cut flowers (Goszczynska and Rudnicki, 1988 and Van Doorn, 2010). Citrate and malate are among the intermediate organic acids in Krebs cycle which produces cellular energy by oxidative phosphorylation (Wills et al., 1981). Citrate complex is one of the mobile forms of iron inside the plant so it plays an important role in iron transport inside plants (Hell and Stephan, 2003).

Malic acid is the organic acid which could be metabolized by the reaction of malic enzyme in mitochondria and considered as ability limited to plant. Malate is a common reserve anion acting as a counter ion for $\mathrm{K}$ and $\mathrm{Ca}$ in plant vacuoles, especially in nitrate dependent plants (Day and Hanson, 1977).

Ramaih et al. (2003) confirmed that tryptophan is the major precursor of Indol Acitic Acid (IAA) in most organisms. Plants produce IAA from tryptophan through indole-3-pyruvic acid (Mashiguchi et al., 2011 and Won, 2011). IAA is also produced from tryptophan through indole-3-acetaldoxime in Arabidopsis (Satoko et al., 2009). El-Bassiouny (2005) demonstrated in increasing the performance of tuberose. In this study, we aimed to test the effect of applying foliar sprays of citric acid, malic acid and tryptophan in increasing the quality and performance of tuberose plant.

\section{MATERIALS AND METHODS}

This study was carried out during the two successive seasons of 2013 and 2014 at the nursery, Department of Floriculture, Ornamental Horticulture and Landscape Gardening, Faculty of Agriculture, Alexandria University, Egypt.

Tuberose (Polianthes tuberosa, L. cv. "Double") corms with an average of $3.8 \mathrm{~cm}$ diameter and $70.0 \mathrm{~g}$ of fresh weight were obtained from a commercial nursery in ElKanater El-Khayreya and planted in $30 \mathrm{~cm}$ diameter plastic pots at a depth of $5 \mathrm{~cm}$ on the $13^{\text {th }}$ of May 2013 and 2014 in the first and second seasons, respectively. The pots were filled with sandy soil (10 kg per pot). The analysis of the sandy soil according to Jackson (1958) are illustrated in Table (1). Before planting, all side buds on the planted corms were removed to allow only the terminal bud to develop in each corm.

The plants were sprayed with Citric acid, Malic acid and Tryptophan at the concentrations of $0,100,200$ and $300 \mathrm{ppm}$, every 15 days starting from the $4^{\text {th }}$ of July till the $15^{\text {th }}$ of August in both seasons. The control plants were sprayed with tap water. the plants and corms were harvested, on the $1^{\text {st }}$ of September in both seasons.

In both seasons, all plants received NPK chemical fertilization using fertilizer (Milagro

Table (1): Chemical analysis of the used sandy soil for the two successive seasons 2013 and 2014.

\begin{tabular}{|c|c|c|c|c|c|c|c|c|c|}
\hline \multirow[t]{2}{*}{ Season } & \multirow[t]{2}{*}{ pH } & \multirow{2}{*}{$\begin{array}{c}\mathrm{EC} \\
\left(\mathbf{d S m}^{-1}\right)\end{array}$} & \multicolumn{4}{|c|}{ Soluble cations (mg/l) } & \multicolumn{3}{|c|}{ Soluble anions (mg/l) } \\
\hline & & & $\mathbf{C a}^{++}$ & $\mathbf{M g}^{++}$ & $\mathrm{Na}^{+}$ & $\mathbf{K}^{+}$ & $\mathrm{HCO}_{3}$ & $\mathrm{Cl}^{-}$ & $\mathrm{SO}_{2}^{-}$ \\
\hline 2013 & 7.87 & 1.51 & 3.1 & 4.2 & 6.4 & 1.1 & 3.5 & 6.5 & 2.4 \\
\hline 2014 & 7.92 & 1.43 & 3.4 & 2.9 & 6.2 & 0.9 & 3.2 & 6.3 & 2.1 \\
\hline
\end{tabular}

that tryptophan and nicotinamide increased IAA, giberellic acid $\left(\mathrm{GA}_{3}\right)$, cytokinens, and decreased abscicic Acid (ABA) in wheat. Nicotinamide is a stress induced compound to provide defense mechanism against a specific stress. Wyszkowska (1999) and El-Bassiouny (2005) observed an increase in some minerals $\mathrm{K}^{+}, \mathrm{Ca}^{2+}$ and $\mathrm{Mg}^{2+}$ in wheat plant tissues by tryptophan treatment.

The present study was conducted to evaluate the use of citric acid, malic acid and tryptophan
Aminoleaf 20-20-20) at the rate of $3 \mathrm{~g} /$ pot. Fertilization was repeated every 30 days throughout the growing season (from the $20^{\text {th }}$ of April till the $15^{\text {th }}$ of August). In addition, weeds were removed manually upon emergence.

\section{Data recorded}

1-Vegetative growth parameters: Plant height $(\mathrm{cm})$, number of leaves per plant, leaf area $\left(\mathrm{cm}^{2}\right)$ and leaf dry weight $(\mathrm{g})$.

2- Flowering characteristics: Time to showing color (day), number of flower per spike, 
flowering duration (day), flower dry weight $(\mathrm{g})$, spike dry weight $(\mathrm{g})$ and rachis length (cm).

3- Corm production: Corm dry weight (g), corm diameter $(\mathrm{cm})$ and number of new cormlets.

\section{4- Chemical analysis determination}

- Chlorophyll content were determined as SPAD units of the fresh leaves of the plants for the different treatments under the experiment at the end of the season using Minolta (chlorophyll meter) SPAD 502 according to Yadava (1986).

- Carbohydrate contents of the leaves were determined according to Dubios et al.(1956).

- Nitrogen (\%) was determined in the digested solution by the modified micro kjeldahl method as described by Pregl, (1945).

The experimental design was a complete randomized block design (RCBD) contained 10 treatments with three replicates; each replicate contained three plants. Data were subjected to analysis of variance (ANOVA) using the SAS program, SAS Institute (Snedecor and Cochran,1974) and the mean the values were compared using L.S.D level (SAS Institute, 2002).

\section{RESULTS AND DISCUSSION \\ 3.1.Vegetative growth \\ 3.1.1. Plant height $(\mathrm{cm})$}

Plant height was significantly affected by spraying the plants with citric acid, malic acid and tryptophan. In both seasons, plant height was increased gradually when the malic acid concentration was raised from $0 \mathrm{ppm}$ (control) to $300 \mathrm{ppm}$. Accordingly, it can be seen from the data in Table (2) that Polianthes tuberosa plants sprayed with $300 \mathrm{ppm}$ malic acid were significantly taller (with mean plant heights of 94.55 and $94.33 \mathrm{~cm}$ in the first and second season, respectively) than plants sprayed with any of citric acid and tryptophan concentrations. The increase in height of Polianthes tuberosa plants as a result of spraying with malic acid is similar to the increases in height that had been recorded on other ornamental plant species, by Darandeh and Hadavi (2012) on Lilium cv. Brunello, Talebi et al. (2014) on Gazania rigens and Kumar et al. (2013) on Tulipa gesneriana.

\subsubsection{Number of leaves per plant}

The effects of citric acid, malic acid and tryptophan treatments on the number of leaves per plant were significant. In the first season, the highest number of leaves per plant (99.10) was formed on plants sprayed with malic acid at 300 ppm, In the case of the second season, the highest number of leaves per plant (95.44) was formed on plants sprayed with malic acid at 200 ppm. On the other hand, the lowest numbers of leaves per plant 84.99 and 84.21 in the first and second seasons, respectively were obtained in the control plants. The increase in the number of leaves of plants sprayed with malic acid at 300 ppm supports the results reported by Kumar et al. (2013) on Tulipa gesneriana.

\subsubsection{Leaf dry weight (g) per plant}

The data presented in Table (2) also show that spraying Polianthes tuberosa plants with malic acid at $300 \mathrm{ppm}$ significantly increased the dry weight of leaves giving values of 19.43 and $18.74 \mathrm{~g}$ per plant in the first and second seasons, respectively, compared to the control (16.66 and $16.51 \mathrm{~g}$ per plant) in the first and second season, respectively. Accordingly, it can be found from the data in Table (2) that Polianthes tuberosa plants sprayed with 300 ppm malic acid gave significantly heaviest leaf dry weight than plants sprayed with any other citric acid and tryptophan concentration. The increase in the leaf dry weight of Polianthes tuberosa plants as a result of spraying with malic acid is similar to the data obtained on other ornamental plant species, by Kazemi (2013) on Strawberry cv. 'Selva' and Talebi et al. (2014) on Gazania rigens.

\subsubsection{Leaf area $\left(\mathrm{cm}^{2}\right)$}

The data presented in Table (2) show that, the different citric acid, malic acid and tryptophan treatments had a significant effect on leaf area of Polianthes tuberosa plants. Plants sprayed with malic acid at $300 \mathrm{ppm}$ formed significantly larger leaves (with a mean area of 1234.89 and $1760.02 \mathrm{~cm}^{2}$ in the first and second season, respectively, than those formed by the control plants $\left(916.89\right.$ and $\left.1185.18 \mathrm{~cm}^{2}\right)$. Similar increases in leaf area as a result of malic acid treatments, have been reported by Kazemi (2013) on Strawberry cv. 'Selva' and Kumar et al. (2013) on Tulipa gesneriana.

Generally, the average plant height due to spraying with malic acid at $300 \mathrm{ppm}$ was 94.55 and $94.33 \mathrm{~cm}$ in first and second seasons, respectively. The extent of any fall in the first grade (Class I) of export (which is how far along spike length between $80-90 \mathrm{~cm}$ ), GOEIC (1988). The plant height for control was 75.99 and $77.22 \mathrm{~cm}$ in first and second seasons, respectively. The extent of any fall in the second 
Table (2): Means of vegetative growth characteristics of Polianthes tuberosa plants as influenced by citric acid, malic acid and tryptophan in the two seasons of 2013 and 2014.

\begin{tabular}{|c|c|c|c|c|c|c|c|c|c|}
\hline \multirow{2}{*}{\multicolumn{2}{|c|}{ Treatments }} & \multicolumn{2}{|c|}{$\begin{array}{l}\text { Plant height } \\
\text { (cm) }\end{array}$} & \multicolumn{2}{|c|}{$\begin{array}{c}\text { Number of } \\
\text { leaves per plant }\end{array}$} & \multicolumn{2}{|c|}{$\begin{array}{l}\text { Leaf dry weight } \\
\text { (g) }\end{array}$} & \multicolumn{2}{|c|}{$\begin{array}{c}\text { Leaf area } \\
\left(\mathrm{cm}^{2}\right)\end{array}$} \\
\hline & & 2013 & 2014 & 2013 & 2014 & 2013 & 2014 & 2013 & 2014 \\
\hline Control & 000 ppm & 75.99 & 77.22 & 84.99 & 84.21 & 16.66 & 16.51 & 916.89 & 1185.18 \\
\hline \multirow{3}{*}{ Citric acid } & 100 ppm & 82.44 & 82.55 & 91.33 & 90.88 & 17.90 & 17.82 & 1062.71 & 1407.99 \\
\hline & 200 ppm & 83.66 & 83.11 & 92.11 & 91.00 & 18.06 & 17.84 & 1114.32 & 1536.38 \\
\hline & 300 ppm & 86.32 & 85.44 & 94.55 & 93.66 & 18.53 & 18.36 & 1181.79 & 1621.42 \\
\hline \multirow{3}{*}{ Malic acid } & 100 ppm & 90.25 & 89.99 & 96.21 & 93.44 & 18.86 & 18.32 & 1095.60 & $\mathbf{1 5 8 8 . 8 5}$ \\
\hline & 200 ppm & 92.55 & 92.66 & 98.32 & 95.44 & 19.27 & 18.71 & 1225.42 & 1671.92 \\
\hline & 300 ppm & 94.55 & 94.33 & 99.10 & 94.44 & 19.43 & 18.74 & 1234.89 & 1760.02 \\
\hline \multirow{3}{*}{ Tryptophan } & $100 \mathrm{ppm}$ & 76.21 & 77.77 & 87.66 & 84.10 & 17.18 & 16.49 & 925.25 & 1244.89 \\
\hline & $200 \mathrm{ppm}$ & 78.66 & 79.66 & 89.99 & 86.55 & 17.64 & 16.97 & $\mathbf{1 0 7 9 . 0 5}$ & 1433.02 \\
\hline & 300 ppm & 79.88 & 80.33 & 91.88 & 87.22 & 18.01 & 17.10 & 1117.81 & 1496.44 \\
\hline \multicolumn{2}{|l|}{ L.S.D. at 0.05} & 1.86 & 1.75 & 4.16 & 6.45 & 0.81 & 1.23 & 144.99 & 58.46 \\
\hline
\end{tabular}

grade (Class $\Pi)$ for export is how far spike length between $70-80 \mathrm{~cm})$, GOEIC (1988).

\subsection{Flowering characteristics}

\subsubsection{Time to showing color (day)}

The data in Table (3-a) showthat considerable differences in the time to showing color (day) were detected in the plants receiving the different concentrations of citric acid, mailc acid and tryptophan treatments. The longest periods (61.33 and 63.00 days in the first and second seasons, respectively), were obtained from plants sprayed with tap water (control) treatment. Whereas, the shortest periods for showing color (47.33 and 49.33 day) in the first and second season, respectively, were obtained from plants sprayed with mailc acid at 300 ppm. Similar results were reported by Kumar et al. (2013) on Tulipa gesneriana.

\subsubsection{Number of flowers per spike}

Concerning the effect of citric acid, malic acid and tryptophan treatments on the number of flowers per spike, the data recorded in Table (3a) show that malic acid treatment at $300 \mathrm{ppm}$ resulted in significant increase in the number of flowers giving mean values of 30.99 and 31.22 flowers per spike in the first and second season, respectively, compared to that of the control plants (23.10 and 22.33 flowers per spike in the two seasons, respectively). The increase in the number of flowers per spike for plants sprayed with malic acid at $300 \mathrm{ppm}$ agreed with the results reported by Kazemi (2013) on Strawberry cv. 'Selva'.

\subsubsection{Flowering duration (day)}

The results in Table (3-a) show that, in both seasons, spraying the plants with citric acid, malic acid and tryptophan increased the flowering duration. Spraying the plants with 300 ppm malic acid gave the highest increase in flowering duration (22.33 and 21.55 days) in the first and second season, respectively. These values were significantly higher than those of the control plants 14.77 and 13.88 days, in the first and second seasons, respectively. Increases in the flowering duration as a result of malic acid treatments had been reported by Kumar et al. (2013) on Tulipa gesneriana.

\subsubsection{Flowers dry weight (g)}

The results recorded in the two seasons in Table (3-b) show that, in both seasons, spraying the plants with citric acid, malic acid and tryptophan increased the dry weight of flowers. Spraying the plants with 300 ppm malic acid gave the heaviest dry weight of flowers 6.45 and $6.22 \mathrm{~g}$ per plant in the first and second season, respectively. These values were significantly higher than those of the control plants (3.27 and $3.10 \mathrm{~g}$ per plant) in the first and second seasons, respectively. Increases in the flowers dry weight as a result of malic acid treatments had been reported by Talebi et al. (2014) on Gazania rigens.

\subsubsection{Spike dry weight (g)}

Spraying Polianthes tuberosa plants with malic acid at 300 ppm gave the heaviest spike dry weight (7.42 and $7.19 \mathrm{~g}$ ) as compared with The control plants giving 5.39 and $5.05 \mathrm{~g}$ in the first and second seasons, respectively. The increase in the spike dry weight of the plants sprayed with malic acid at 300 ppm supports the results reported by Talebi et al. (2014) on Gazania rigens.

\subsubsection{Rachis length (cm)}

The data in Table (3-b) indicate that citric 
acid, malic acid and tryptophan treatments had a significant effect on the rachis length. In both seasons, plants sprayed with malic acid gave the tallest rachis length compared to the control plants. As with other flowering characteristic parameters, spraying the plants with malic acid at $300 \mathrm{ppm}$ gave the tallest rachis length 30.50 and $30.42 \mathrm{~cm}$ in the first and second season, respectively. Similar increase in the rachis length as a result of malic acid treatments was recorded by Talebi et al. (2014) on Gazania rigens.

Generally, the average flower it was number per spike when sprayed with malic acid at 300 ppm was 30.99 and 31.22 in the first and second seasons, respectively. The extent of any fall in the first grade (Class I) of export is how far along flower number per spike between 25-30 flowers, GOEIC (1988). We found that the flower number per spike in the control was 23.10 and 22.33 in the first and second season, respectively. The extent of any fall in the second grade (Class $\Pi$ ) for export is how far along flower number per spike between $20-25$ flowers, GOEIC (1988).

\subsection{Corm production}

\subsubsection{Corm dry weight (g)}

The data recorded in Table (4) showed that spraying Polianthes tuberosa plants with tryptophan to $200 \mathrm{ppm}$ gave the heaviest values of corm dry weight (20.32 and $23.32 \mathrm{~g})$ as compared with the control treatment which gave 14.27 and $18.31 \mathrm{~g}$ in the first and second season, respectively. The increase in the corm dry weight due to spraying with tryptophan at 200 ppm supports the results reported by Hussein et al. (2014) on onion plants and Kumar et al. (2013) on Tulipa gesneriana.

\subsubsection{Corm diameter $(\mathbf{c m})$}

The data recorded in Table (4) showed that spraying Polianthes tuberosa plants with malic

Table (3-a): Means of flowering characteristics of Polianthes tuberosa plants as influenced by citric acid, malic acid and tryptophan in the two seasons of 2013 and 2014.

\begin{tabular}{|c|c|c|c|c|c|c|c|}
\hline \multirow{2}{*}{\multicolumn{2}{|c|}{ Treatments }} & \multicolumn{2}{|c|}{$\begin{array}{l}\text { Time to showing } \\
\text { color (day) }\end{array}$} & \multicolumn{2}{|c|}{$\begin{array}{l}\text { Number flower } \\
\text { per spike }\end{array}$} & \multicolumn{2}{|c|}{$\begin{array}{c}\text { Flowering duration } \\
\text { (day) }\end{array}$} \\
\hline & & 2013 & 2014 & 2013 & 2014 & 2013 & 2014 \\
\hline Control & 000 ppm & 61.33 & 63.00 & 23.10 & 22.33 & 14.77 & 13.88 \\
\hline \multirow{3}{*}{ Citric acid } & $100 \mathrm{ppm}$ & 57.66 & 60.66 & 26.99 & 25.88 & 17.33 & 16.21 \\
\hline & $200 \mathrm{ppm}$ & 55.33 & $\mathbf{5 8 . 0 0}$ & 26.77 & 27.33 & 18.33 & 17.10 \\
\hline & $300 \mathrm{ppm}$ & 52.00 & 55.33 & 28.44 & 27.99 & 19.22 & 18.88 \\
\hline \multirow{3}{*}{ Malic acid } & $100 \mathrm{ppm}$ & $\mathbf{5 5 . 3 3}$ & 58.00 & 29.11 & 27.44 & 20.22 & 19.99 \\
\hline & $200 \mathrm{ppm}$ & 50.66 & $\mathbf{5 3 . 3 3}$ & 30.21 & 29.55 & 21.44 & 20.21 \\
\hline & 300 ppm & 47.33 & 49.33 & 30.99 & 31.22 & 22.33 & 21.55 \\
\hline \multirow{3}{*}{ Tryptophan } & $100 \mathrm{ppm}$ & 60.66 & 63.33 & 24.44 & 23.33 & 16.10 & 14.88 \\
\hline & $200 \mathrm{ppm}$ & 58.66 & 61.00 & 25.44 & 24.66 & 15.77 & 15.55 \\
\hline & $300 \mathrm{ppm}$ & $\mathbf{5 8 . 3 3}$ & 60.00 & 26.44 & 26.33 & 17.77 & 17.55 \\
\hline \multicolumn{2}{|l|}{ L.S.D. at 0.05} & 0.98 & 1.32 & 1.33 & 0.83 & 1.82 & 1.46 \\
\hline
\end{tabular}

Table (3-b): Means of flowering characteristics of Polianthes tuberosa plants as influenced by citric acid, malic acid and tryptophan in the two seasons of 2013 and 2014.

\begin{tabular}{|c|c|c|c|c|c|c|c|}
\hline \multirow{2}{*}{\multicolumn{2}{|c|}{ Treatments }} & \multicolumn{2}{|c|}{ Flower dry weight (g) } & \multicolumn{2}{|c|}{ Spike dry weight (g) } & \multicolumn{2}{|c|}{ Rachis length $(\mathrm{cm})$} \\
\hline & & 2013 & 2014 & 2013 & 2014 & 2013 & 2014 \\
\hline Control & 000 ppm & 3.27 & 3.10 & 5.39 & 5.05 & 24.51 & 24.90 \\
\hline \multirow{3}{*}{ Citric acid } & $100 \mathrm{ppm}$ & 4.37 & 4.55 & 5.82 & 6.89 & 26.59 & 26.62 \\
\hline & $200 \mathrm{ppm}$ & 4.94 & 4.79 & 6.27 & 5.73 & 26.98 & 26.80 \\
\hline & $300 \mathrm{ppm}$ & 5.94 & 5.79 & 6.66 & 7.66 & 27.84 & 27.56 \\
\hline \multirow{3}{*}{ Malic acid } & $100 \mathrm{ppm}$ & 5.87 & 5.69 & 6.42 & 8.18 & 29.11 & 29.03 \\
\hline & $200 \mathrm{ppm}$ & 6.20 & 5.94 & 7.01 & 8.92 & 29.85 & 29.89 \\
\hline & $300 \mathrm{ppm}$ & 6.45 & 6.22 & 7.42 & 7.19 & 30.50 & 30.42 \\
\hline \multirow{3}{*}{ Tryptophan } & $100 \mathrm{ppm}$ & 3.37 & 3.21 & 5.51 & 4.80 & 24.58 & 25.08 \\
\hline & $200 \mathrm{ppm}$ & 4.45 & 4.30 & 5.95 & 6.00 & 25.37 & 25.69 \\
\hline & $300 \mathrm{ppm}$ & 4.77 & 4.62 & 6.08 & 6.34 & 25.76 & 25.91 \\
\hline \multicolumn{2}{|l|}{ L.S.D. at 0.05} & 0.40 & 0.09 & 0.33 & 0.56 & 0.60 & 0.56 \\
\hline
\end{tabular}


acid up to $300 \mathrm{ppm}$ gave the largest corm diameter 6.69 and $6.42 \mathrm{~cm}$ in the first and second seasons, respectively. Whereas, it was found that spraying with tap water (control) decreased the bulb diameter $(5.38$ and $5.12 \mathrm{~cm})$ as compared with other treatments in the first and second seasons, respectively. The increase in the corm diameter due to spraying with malic acid at 300 ppm supports the results reported by Kumar et al. (2013) on Tulipa gesneriana.

\subsubsection{Number of cormlets per plant}

The data show that plants sprayed with malic acid at 300 ppm formed the highest number of cormlets per plant which gave 24.66 and 20.16 in the first and second seasons, respectively. Whereas, the control plants gave the lowest number of cormlets per plant 13.83 and 11.33 in the first and second season, respectively. The increase in the number of cormlets per plant due to spraying with malic acid at 300 ppm supports the results reported by Kumar et al. (2013) on Tulipa gesneriana.

\subsection{Chemical constituents}

\subsubsection{Total chlorophyll content (SPAD unit)}

The results obtained in Table (5) show that citric acid, malic acid and tryptophan treatments had clear effect on the total chlorophyll content. The highest mean values (37.88 and 38.56 SPAD) in the first and second seasons, respectively, were obtained from in plants sprayed with malic acid at $300 \mathrm{ppm}$ as compared with (31.56 and 30.33 SPAD) for the control plants, in the first and second season, respectively. Similar results were reported by Darandeh and Hadavi (2012) on Lilium cv. Brunello and Kazemi et al. (2012) on carnation.

\subsubsection{Total carbohydrate content $(\%)$}

The results in Table (5) also show that most of the tested citric acid, malic acid and tryptophan concentrations increased the mean

Table (4): Means of corm production of Polianthes tuberosa plants as influenced by citric acid, malic acid and tryptophan in the two seasons of 2013 and 2014.

\begin{tabular}{|c|c|c|c|c|c|c|c|}
\hline \multirow{2}{*}{\multicolumn{2}{|c|}{ Treatments }} & \multicolumn{2}{|c|}{ Corm dry weight (g) } & \multicolumn{2}{|c|}{ Corm diameter $(\mathrm{cm})$} & \multicolumn{2}{|c|}{ Number New Cormlets } \\
\hline & & 2013 & 2014 & 2013 & 2014 & 2013 & 2014 \\
\hline Control & 000 ppm & 14.27 & 18.31 & 5.38 & 5.12 & 13.83 & 11.33 \\
\hline \multirow{3}{*}{ Citric acid } & $100 \mathrm{ppm}$ & 14.77 & 17.90 & 5.76 & 5.50 & 16.83 & 15.16 \\
\hline & 200 ppm & 16.69 & 20.59 & 5.85 & 5.66 & 17.66 & 16.33 \\
\hline & $300 \mathrm{ppm}$ & $\mathbf{1 7 . 5 3}$ & 21.05 & 6.03 & 6.05 & 18.33 & 17.33 \\
\hline \multirow{3}{*}{ Malic acid } & 100 ppm & 17.62 & 21.26 & 6.36 & 6.24 & 22.50 & 17.00 \\
\hline & 200 ppm & 16.38 & 20.07 & 6.58 & 6.34 & 23.66 & 18.33 \\
\hline & 300 ppm & 18.86 & 22.37 & 6.69 & 6.42 & 24.66 & 20.16 \\
\hline \multirow{3}{*}{ Tryptophan } & 100 ppm & 19.92 & 22.83 & 5.56 & 5.26 & 14.83 & 12.50 \\
\hline & $200 \mathrm{ppm}$ & 20.32 & 23.32 & 5.82 & 5.47 & 15.83 & 13.33 \\
\hline & 300 ppm & 17.91 & 21.94 & 5.82 & 5.58 & 16.66 & 14.33 \\
\hline \multicolumn{2}{|l|}{ L.S.D. at 0.05} & 0.72 & 0.15 & 0.21 & 0.22 & 0.55 & 1.04 \\
\hline
\end{tabular}

Table (5): Means of chemical constituents of Polianthes tuberosa plants as influenced by citric acid, malic acid and tryptophan in the two seasons of 2013 and 2014.

\begin{tabular}{|c|c|c|c|c|c|c|c|}
\hline \multicolumn{2}{|c|}{ Treatments } & \multicolumn{2}{|c|}{$\begin{array}{l}\text { Total chlorophyll } \\
\text { content (SPAD) }\end{array}$} & \multicolumn{2}{|c|}{$\begin{array}{l}\text { Total Carbohydrate } \\
\text { content in corm }(\%)\end{array}$} & \multicolumn{2}{|c|}{$\begin{array}{l}\text { Nitrogen Conten } \\
\text { in leaves }(\%)\end{array}$} \\
\hline & & 2013 & 2014 & 2013 & 2014 & 2013 & 2014 \\
\hline Control & 000 ppm & 31.56 & 30.33 & 22.93 & 24.51 & 0.88 & 0.68 \\
\hline \multirow{3}{*}{ Citric acid } & $100 \mathrm{ppm}$ & 34.06 & 33.64 & 24.10 & 25.52 & 1.08 & 0.88 \\
\hline & 200 ppm & 33.80 & 34.82 & 24.47 & 26.13 & 1.21 & 1.01 \\
\hline & 300 ppm & 35.03 & 35.99 & 25.83 & 26.97 & 1.47 & 1.27 \\
\hline \multirow{3}{*}{ Malic acid } & 100 ppm & 35.76 & 36.97 & 26.57 & 27.30 & 1.52 & 1.32 \\
\hline & 200 ppm & 36.52 & 37.80 & 26.91 & 27.84 & 1.77 & 1.57 \\
\hline & 300 ppm & 37.88 & 38.56 & 27.96 & 27.94 & 1.91 & 1.71 \\
\hline \multirow{3}{*}{ Tryptophan } & 100 ppm & 32.59 & 31.68 & 23.33 & 23.28 & 0.96 & 0.76 \\
\hline & 200 ppm & 33.33 & 32.30 & 23.81 & 25.70 & 1.14 & 0.94 \\
\hline & 300 ppm & 33.76 & 33.16 & 24.11 & 25.82 & 1.21 & 1.01 \\
\hline \multicolumn{2}{|l|}{ L.S.D. at 0.05} & 0.71 & 0.74 & 0.63 & 0.45 & 0.004 & 0.004 \\
\hline
\end{tabular}


total carbohydrates \% in the corms of Polianthes tuberosa plants, compared to the control. It was found that the plants sprayed with $300 \mathrm{ppm}$ malic acid contained the highest total carbohydrates \% in the corms of 27.96 and 27.94 $\%$ in the first and second season, respectively.

\subsubsection{Nitrogen percentage in the leaves}

The results in Table (5) also show that the mean value of nitrogen in the leaves was slightly increased by spraying the plants with $300 \mathrm{ppm}$ malic acid which gave nitrogen contents of 1.91 and $1.71 \%$ as compared with 0.88 and $0.68 \%$ for the control plants in the first and second seasons, respectively.

\section{Conclusions}

Our results reveal a positive effect of applied organic acids on the vegetative growth, flowering characteristics and corm production. This indicates that these organic acids could improve the ornamental value of tuberose as a cut flowers plant. The increase in our experiment could be considered relatively similar with the previous findings obtained from spraying malic and citric acid as reported by Eidyan et al. (2014) on tuberose, Darandeh and Hadavi (2012) on lilium, and Jafari and Hadavi (2012) on dill plant. However, our results show for the first time that both organic acids increased the lifespan of attached flowers to the plant. The taller plants in response to spraying of both organic acids are consistent with that earlier reported by Jafari and Hadavi (2012) on dill plant, where it was observed that both organic acids and their combination resulted in taller dill plants.

Citric acid and malic acid possibly affected carbohydrates content in corm under our study. Citric acid and malic acid as they affect the plants in relatively high concentrations, a distinct pattern of regulative effects could be noted. The fact that organic acids affect plants in higher concentrations. These are both environmentfriendly and low cost agents.

\section{REFERENCES}

Darandeh N. and Hadavi E. (2012). Effect of pre-harvest foliar application of citric acid and malic acid on chlorophyll content and post-harvest vase life of Lilium cv. Brunello. Frontiers in Plant Science: Crop Sci. and Hort., vol. 2, article 106, pp. 1-3.

Day D. A. and Hanson J. B. (1977). Pyruvate and malate transport and oxidation in corn mitochondria. Plant Physiol 59(4): 630-635.
Dubios M., Gilles K., Hamlton J., Rebers P., and Smith F.(1956). Colourimetric method for determination of sugars and related substances. Analy. Chem., 28(3):350- 356.

Eidyan B., Hadavi E., and Moalemi N. (2014). Pre-harvest foliar application of iron sulfate and citric acid combined with urea fertigation affects growth and vase life of tuberose (Polianthes tuberosa L.) 'PorPar'. Hort. Environ. and Biotech., 55, no. 1, pp. 9-13.

El-Bassiouny H. M. (2005). Physiological responses of wheat to salinity alleviation by nicotinamide and tryptophan. Int. J. Agric. and Biol., 7: 654-660.

General Organization for Export and Import Control (GOEIC). (1988). Quality specifications of medicinal plants and aromatic oils and flowers exported. Ministry of Trade, Industry and Investment. p. $49-50$.

Goszczynska D. M. and Rudnicki R. M. (1988). Storage of Cut Flowers, Horticultural Reviews. John Wiley \& Sons, Inc., 35-62. New York, USA.

Hell R. and Stephan U. W. (2003). Iron uptake, trafficking and homeostasis in plants. Planta, 216: 541-551.

Hussein M.M., Faham S. Y. and Alva A. K. (2014). Role of foliar application of nicotinic acid and tryptophan on onion plants response to salinity stress. J. Agric. Sci., 6 (8): 41-51.

Jackson N. L. (1958). Soil Chemical Analysis. Constable. Ltd. Co., London, UK.498 p.

Jafari N. and Hadavi E. (2012). Growth and essential oil yield of dill (Anethum graveolens) as affected by foliar sprays of citric acid and malic acid. Acta Hort. 955:287-290.

Kazemi M. (2013). Influence of foliar application of 5-Sulfo salicylic acid, malic acid, putrescine and potassium nitrate on vegetative growth and reproductive characteristics of strawberry cv. 'Selva'., J. Biol. Environ. Sci., 7 (20): 93-101.

Kazemi M., Hadavi E. and Hekmati J. (2012). Effect of salicylic acid, malic acid, citric acid and sucrose on antioxidant activity, membrane stability and ACC-Oxidase activity in relation to vase life of carnation cut flowers. J. Agric. Tech. 8(6): 2053-2063.

Kumar R., Ahmed N., Singh D., Sharma O., Lal S. and Salmani M. (2013). Enhancing 
blooming period and propagation coefficient of tulip (Tulipa gesneriana L.) using growth regulators. Afr. J. Biotech., 12(2), 168-174.

Mashiguchi K., Tatsuya T., Sugawara S., Kawaide H., Natsume M., Hanadaa A. and Kasahara H. (2011). The main auxin biosynthesis pathway in Arabidopsis. P.N.A.S., (Early ed., pp. 1-6).

Pregl F. (1945). Quantitative Organic Micro Analysis. $4^{\text {th }}$ Ed. J. A. Churchil. Ltd., London, UK, $539 \mathrm{p}$.

Ramaih S., Geudira M., and Paulsen G. M. (2003). Relationship of indole acetic acid and tryptophan dormancy and pre-harvest sprouting of wheat. Funct. Plant Biol.30: 939-945.

SAS Institute (2002). SAS user guide and program 20, version 9.0.38. cary, NC27513.

Satoko S., Shojiro H., Yusuke J., Atsushi H., Takeshi N. and Yuji K. (2009). Biochemical analyses of indole-3acetaldoxime - dependent auxin biosynthesis in Arabidopsis. P.N.A.S., USA, 106, 5430-5435.

Snedecor G. and Cochran W. (1974). Statistical Methods. $7^{\text {th }}$ Ed. The Iowa State Univ. Press, Ames, Iowa, USA, ISBN 9780815381560, 97808153815602.

Steenstra D. R. and Brundell D. J. (1986). "Tuberose: Cultivation, Cut Flower Production", Ministry of Agriculture and Fisheries Information Bulletin 187, Wellington, New Zealand, 3.
Talebi M, Hadavi E. and Jaafari N. ( 2014). Foliar sprays of citric acid and malic acid modify growth, flowering, and root to shoot ratio of Gazania (Gazania rigens L.): A Comparative Analysis by ANOVA and Structural Equations Modeling. Adv. Agric. Article ID 147278, 1-6.

Trueblood E. W. E. (1973). The tuberose (Polianthes tuberose L.). Econ. Bot., 27, 157.

Van Doorn W. G. (2010). Water Relations of Cut Flowers, Horticultural Reviews.: John Wiley \& Sons, Inc., 1-85, New York, USA.

Wills R., Lee T., Graham D., McGlasson W. and Hall E. (1981). Postharvest. An Introduction to the Physiology and Handling of Fruit and Vegetables. Willingford: CAB International, Hyde Press, Adelaide, South Australia, 50 p.

Won C. (2011). Conversion of tryptophan to indole-3-acetic acid by tryptophan aminotransferases of Arabidopsis and yuccas in arabidopsis. P.N.A.S., USA, 108, 18518-18523.

Wyszkowska J. (1999). Modification of faba bean chemical composition caused by precursors of plant growth regulators \& soil microorganism. Effect of Ltryptophan and beta-indolyl acitic acid. Biuletyn-naukowy, 5:56-63.

Yadava U. (1986). A rapid and non destructive method to determine chlorophyll in intact leaves. Hort. Sci., 21(6): 1449-1450.

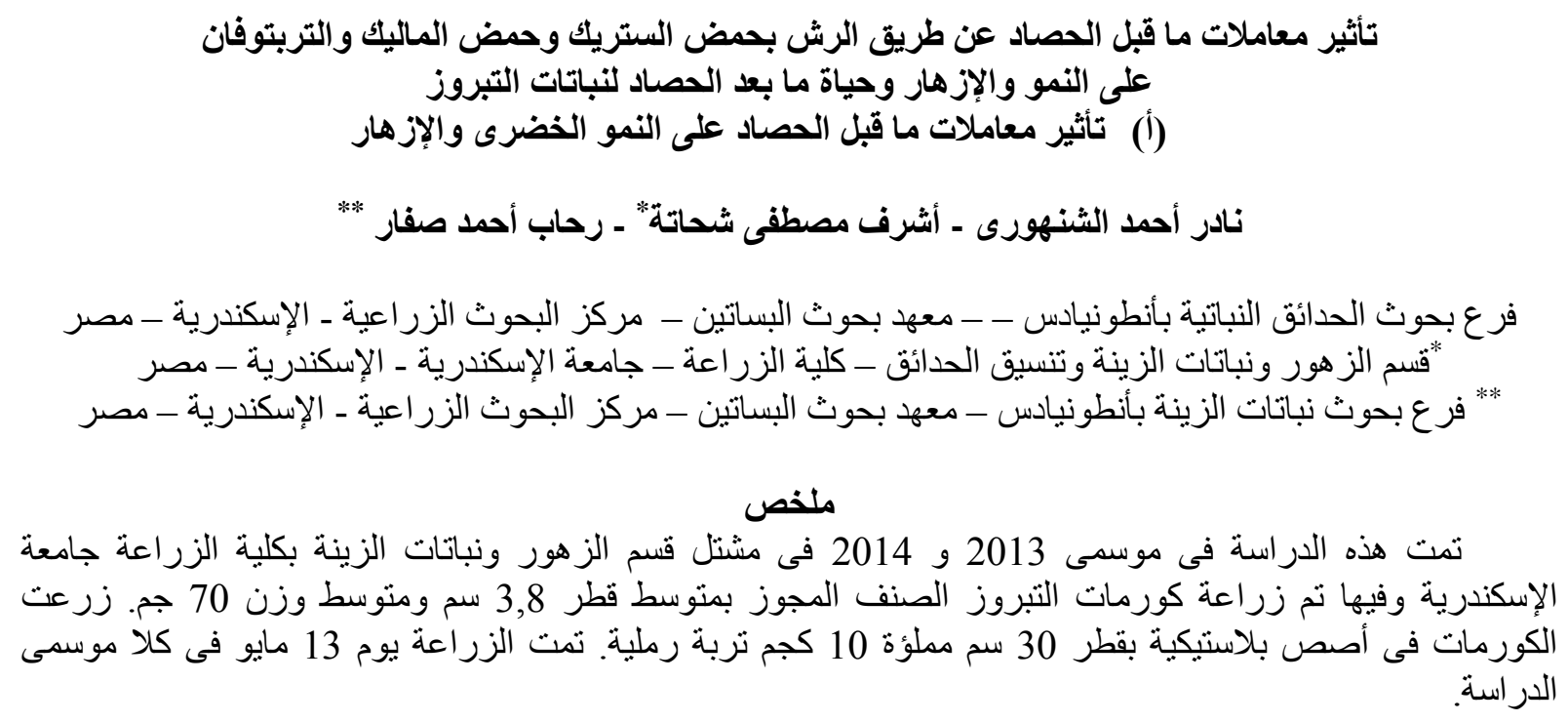




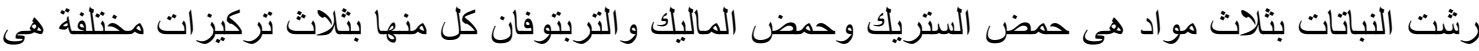

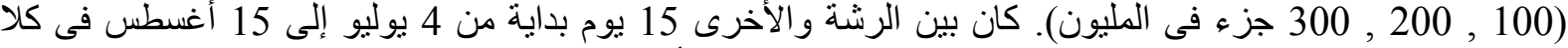

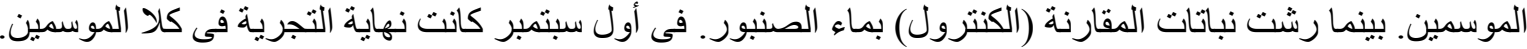

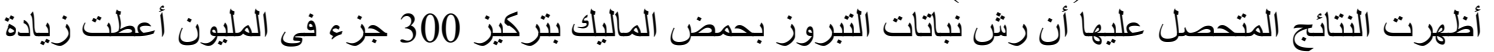

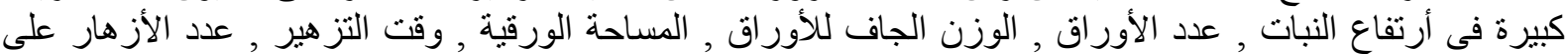

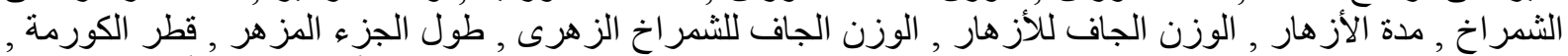

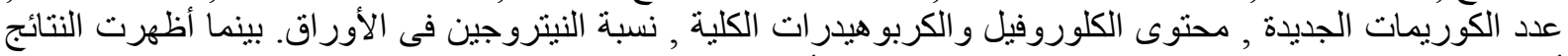

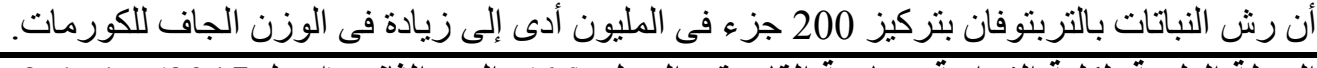

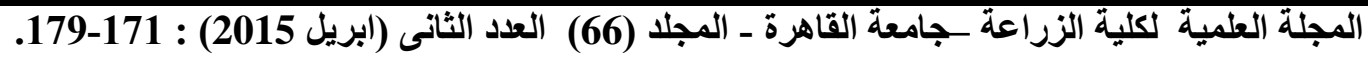

